\title{
THERMAL COMFORT INDICES IN INDIVIDUAL SHELTERS FOR DAIRY CALVES WITH DIFFERENT TYPES OF ROOFS
}

\section{PATRÍCIA C. DE F. FONSECA ${ }^{1}$, EDUARDO A. DE ALMEIDA ${ }^{2}$, ROBERTA PASSINI ${ }^{3}$}

\begin{abstract}
Among the building materials used in rural facilities, roofs are noteworthy for being largely responsible for thermal comfort, influencing the thermal balance within the shelter. This study aimed to evaluate the influence of roof on the Enthalpy $(\mathrm{H})$, Thermal Load of Radiation (TLR), and Black Globe Temperature and Humidity Index (BGHI) in individual shelters for dairy calves. The design was completely randomized with three treatments: $\mathrm{Z}$ - zinc tile, AC - asbestoscement tile and ACW - asbestos-cement tile painted white on the upper side. The averages were compared by the Scott Knott test at $1 \%$ probability. The results showed no statistical difference between treatments $(\mathrm{P}<0.01)$ and the external environment for $\mathrm{H}$. For TLR, there was statistical difference among all treatments, where ACW showed the lowest TLR, $489.28 \mathrm{~W} \mathrm{~m}^{-2}$, followed by $\mathrm{AC}$ with $506.72 \mathrm{~W} \mathrm{~m}^{-2}$ and $\mathrm{Z}$ with the highest TLR, $523.55 \mathrm{~W} \mathrm{~m}^{-2}$. For BGHI, the lowest values were observed for ACW (76.8) and AC (77.4), differing significantly from Z, which obtained the highest value (81.6). The tiles with white paint on the upper side promoted the lowest TLR and the lowest BGHI, favoring the thermal environment in the shelter.
\end{abstract}

KEYWORDS: thermal indices, construction materials and type of roof.

\section{AMBIENTE TÉRMICO NO INTERIOR DE ABRIGOS INDIVIDUAIS PARA BEZERROS COM A UTILIZAÇÃO DE DIFERENTES TIPOS DE COBERTURAS}

RESUMO: Dentre os materiais de construção utilizados nas instalações rurais, merecem destaque as coberturas, pois são grandes responsáveis pelo conforto térmico, influenciando no balanço térmico no interior das instalações. Este trabalho objetivou avaliar a influência das coberturas sobre a entalpia (H), Carga Térmica Radiante (CTR) e no Índice de Temperatura de Globo Negro e Umidade (ITGU), em abrigos individuais para bezerros leiteiros. O delineamento foi o inteiramente casualizado com três tratamentos: $\mathrm{Z}$ - telha de zinco; $\mathrm{CA}$ - telha de cimento amianto, e CAB - telha de cimento amianto pintada de branco na face superior. As médias foram comparadas pelo teste de Scott Knott, a 1\% de probabilidade. Os resultados mostraram que não houve diferença estatística entre os tratamentos $(\mathrm{P}<0,01)$ e o ambiente externo, para a $\mathrm{H}$. Para a CTR, houve diferença estatística entre todos os tratamentos, em que CAB demonstrou menor CTR, 489,28 $\mathrm{W} \mathrm{m}^{-2}$, seguido do tratamento $\mathrm{CA}, 506,72 \mathrm{~W} \mathrm{~m}^{-2}$, e $\mathrm{Z}$ com maior valor de CTR, 523,55 $\mathrm{W} \mathrm{m}^{-2}$. Para o ITGU, observaram-se menores valores para $\mathrm{CAB}(76,8)$ e CA $(77,4)$, diferindo-se, significativamente do Z, que obteve maior valor $(81,6)$. As telhas com pintura branca em sua face superior promoveram menor CTR e menor ITGU, favorecendo o ambiente térmico da instalação.

PALAVRAS-CHAVE: índices térmicos, materiais de construção e tipo de cobertura.

\footnotetext{
${ }^{1}$ Mestre em Engenharia Agrícola, Docente Universidade Estadual de Goiás, UEG, Anápolis - GO.

${ }^{2}$ Mestrando em Zootecnia, Faculdade de Ciências Agrárias e Veterinárias, UNESP, Jaboticabal - SP.

${ }^{3}$ Doutora em Zootecnia, Docente Universidade Estadual de Goiás, UEG, Anápolis - GO.

Recebido pelo Conselho Editorial em: 31-5-2010

Aprovado pelo Conselho Editorial em: 31-8-2011
} 


\section{INTRODUCTION}

Over the last decades, Brazil is standing out worldwide as a major milk producer, but at the same time, the country suffers from a lack of technical resources and regional studies, which contributes to high losses and low productivity levels (MILANI \& SOUZA, 2010).

In dairy farming, one of the most important activities is raising of the calves, which determines the sustainability of production systems, i.e., the renewal of the herd (CAMPOS et al., 2005).

The use of individual shelters is an alternative to raise calves due to advantages such as lower cost and ease of cleaning (FERREIRA, 2005). According to BAÊTA \& SOUZA (2010), the use of shelters with a wide variety of roofing materials (shade, asbestos-cement, etc.) promotes up to $30 \%$ reduction of the radiant heat load when compared to the load the animal would receive outside, thus improving the thermal comfort condition.

WEST (2003) stressed the importance of materials used in the manufacture of roofs with properties that allow better sunlight reflection in order to reduce the thermal indices in the shelter, according to FIORELLI et al. (2009), Brazil is more concerned with heat than to cold regarding animal stresses.

According to CONCEIÇÃO et al. (2008), most installations use roof with corrugated sheets, such as asbestos-cement because the current construction cost is lower than that of ceramic tiles, mainly due to the fact that the support structure is lighter and uses the least amount of labor. In addition, this construction is faster and easier to clean, justifying the preference of this roof type (TCPO, 2008).

A trick widely used in animal production facilities is the use of reflective paint on the outside of the roof. According to SARMENTO et al. (2005), white color in the outer surface of the roof is a simple and effective device to reduce the temperature of the inner surface of the cover, by reducing up to $9.0^{\circ} \mathrm{C}$ of the temperature in the hottest times of the day.

It is noteworthy that the decrease in stress conditions significantly increases the animal comfort thus resulting in better production (PERISSINOTTO et al., 2006; NAVARINI et al., 2009).

In order to determine levels of thermal comfort in the environmental conditions, several indices have been developed. One of the thermal comfort indexes most widely used is the black globe humidity index (BGHI), developed by BUFFINGTON et al. (1981).

BGHI has the advantage of incorporating into a single value, called the black globe temperature, the effects of convection, air temperature, humidity, ventilation and radiation (MEDEIROS et al., 2005). According to BUFFINGTON et al. (1981), in environmental conditions which animals are exposed to solar radiation, BGHI is the most accurate stress indicator.

Another indicator of the environmental thermal conditions is the thermal load of radiation (TLR), which expresses the total radiation received by a body from all the surrounding space. From the bioclimatic point of view, one of the main factors that influence the thermal load of radiation is the roof, mainly because of the roof materials (SILVA \& SEVEGNANI, 2001).

This study aimed to evaluate the degree of thermal comfort in shelters of individual Holstein calves with the use of asbestos-cement and zinc roofing. These covers were chosen because they are the most used materials in this type of facility in the region under study.

\section{MATERIAL AND METHODS}

The experiment was carried out from March to May 2009 at the Fazenda Sol Dourado, currently the only property in the state of Goiás processing type A milk. The ranch is located on 437 highway, in the municipality of Gameleira - GO. The town has the following coordinates: $16^{\circ} 25^{\prime} 29.68^{\prime \prime}$ S latitude, $48^{\circ} 48^{\prime} 11.55^{\prime}$ ' $\mathrm{W}$ longitude, and about $1,032 \mathrm{~m}$ altitude. The classification 
of the local climate, according to Köppen, is Aw, with mesoclimate characteristic rainfall regimen of semi-humid tropical climate with a well-defined dry season and hot thermal regime.

Roofs were assessed in individual shelters with dimensions of $1.00 \mathrm{~m}$ wide, $1.50 \mathrm{~m}$ deep and $1.20 \mathrm{~m}$ high in the front and $1.00 \mathrm{~m}$ in the back (Figure 1). The sides were sealed with $0.26 \mathrm{~mm}$ thick galvanized zinc plates (Figure 2). The shelters were arranged in the longitudinal axis East West, keeping a distance of approximately 2 meters between them.

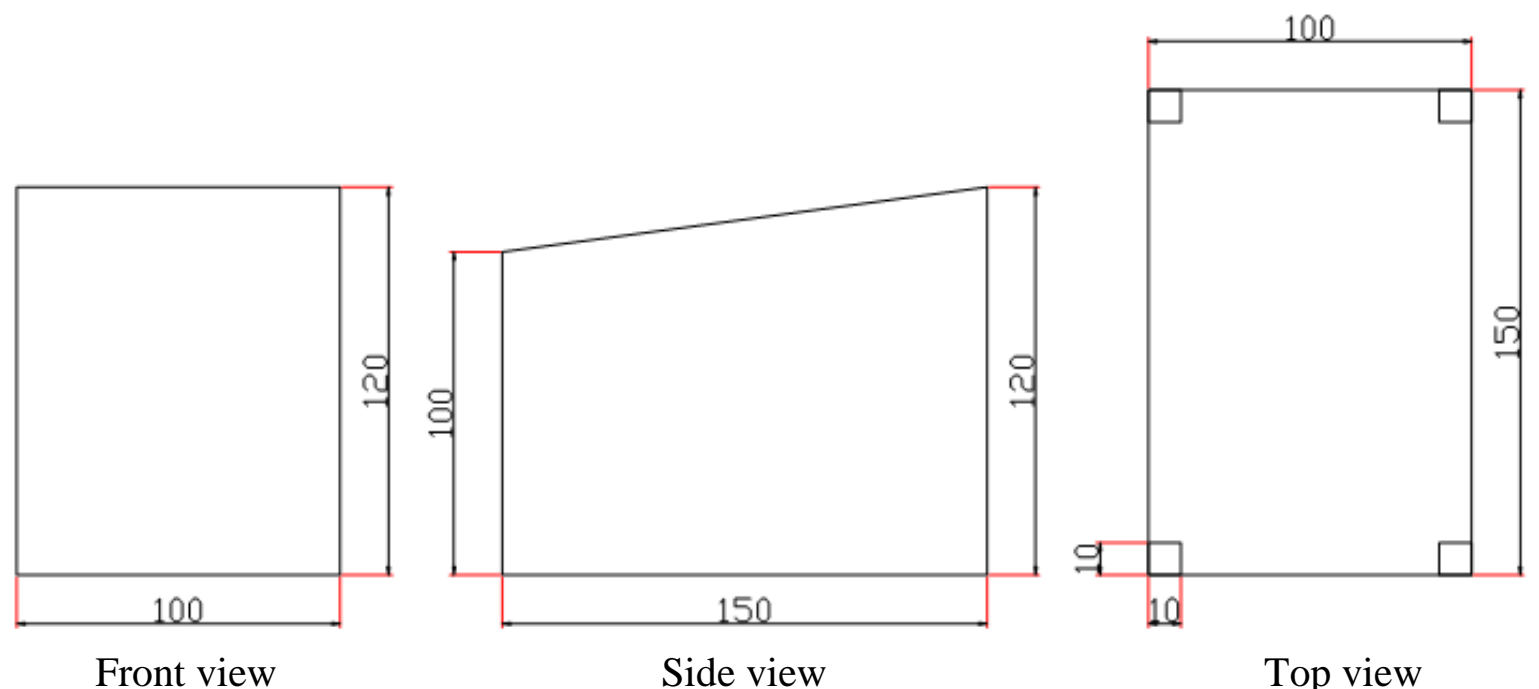

FIGURE 1. Front, side and top views of the shelters.

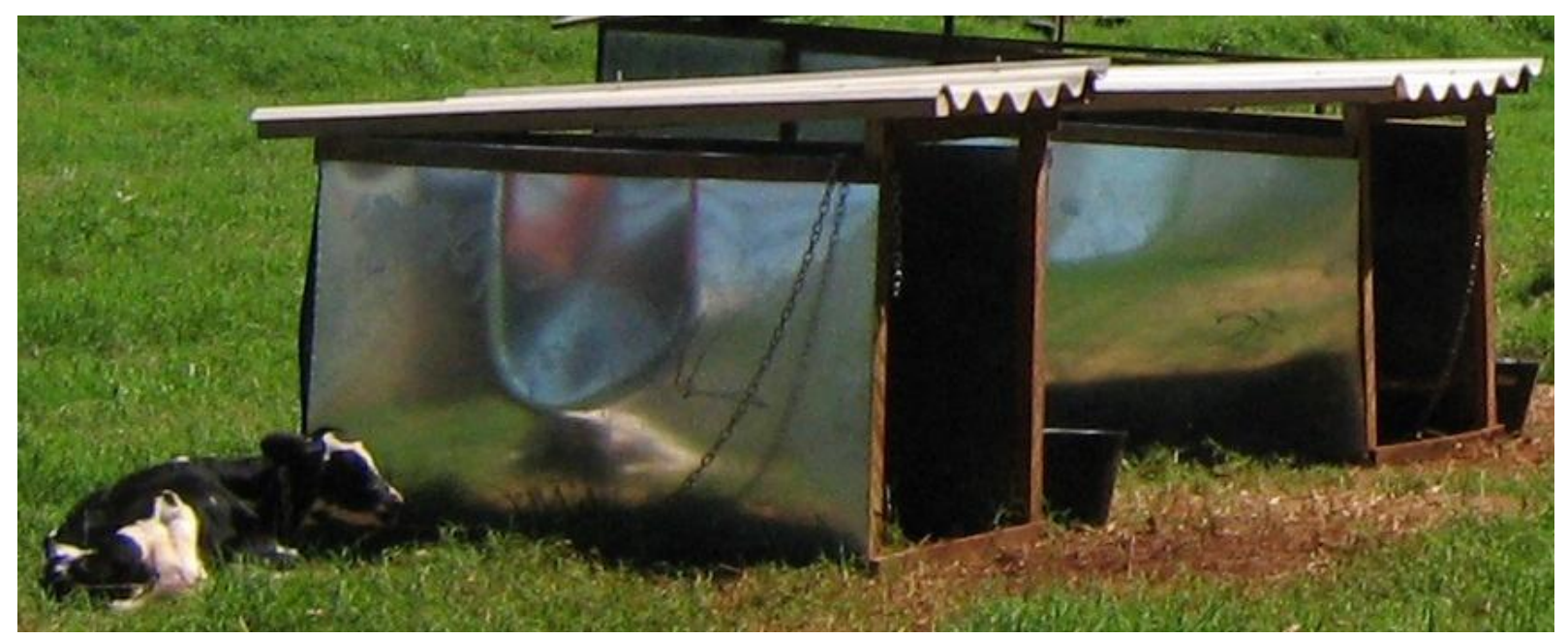

FIGURE 2. Individual shelters.

The following environmental variables were collected inside each shelter: black globe temperature, relative humidity and dry bulb temperature. Globe thermometers made of plastic spheres painted with matte black paint with a mercury thermometer in the internal central region were used to obtain the black globe temperature. All thermometers were previously calibrated. The relative humidity and dry bulb temperature were collected with a thermohygrometer with scale of 0 to $100 \%$ relative humidity (accuracy of $\pm 1 \%$ ), and range from $-15{ }^{\circ} \mathrm{C}$ to $55^{\circ} \mathrm{C}$ for room temperature (accuracy $\pm 1^{\circ} \mathrm{C}$ ). The black globe and thermohygrometer were installed inside the shelter, at a height of approximately $80 \mathrm{~cm}$ of the ground, representing the center of the installation.

Data were collected during 70 days at $9 \mathrm{am}, 11 \mathrm{am}$ and $1 \mathrm{pm}$, with each day as a repetition. To calculate the enthalpy $(\mathrm{H})$, the Grapsi®program developed by MELO et al. (2004) was used, which is capable of calculating the psychrometric properties of the air. The data reported to the program were air temperature, relative humidity and local altitude. 
A digital Hygro-Thermo-Anemometer light meter, model LS8000, was installed close to the shelters to collect environmental data external to the facilities. The data collected were dry bulb temperature, relative humidity, wind speed and dew point. For wind speed, the local wind speed in the external environment was used.

From the environmental data collected, thermal comfort indices were calculated.

To measure the radiant thermal load, the Thermal Load of Radiation (TLR, W.m ${ }^{-2}$ ) was calculated from the equation proposed by ESMAY (1979):

$$
\mathrm{TLR}=\sigma(\mathrm{MRT})^{4}
$$

where,

$\sigma$ - Stefan-Boltzmann constant $\left(5,67.10^{-8} \mathrm{~W} \mathrm{~m}^{-2} \mathrm{~K}^{-4}\right)$; and

MRT - mean radiant temperature, $\mathrm{K}$.

MRT is expressed by the equation 2:

$$
M R T=100\left[2.51 \cdot(W)^{0.5} \cdot(T b g-T d b)+\left(\frac{T b g}{100}\right)^{4}\right]^{\frac{1}{4}}
$$

where,

$\mathrm{W}$ - wind speed, $\mathrm{m} \mathrm{s}^{-1}$;

Tbg - temperature of the black globe, $\mathrm{K}$; and

$\mathrm{Tdb}$ - temperature of dry bulb, K.

In order to describe the degree of environmental thermal comfort, it was used the black globe temperature and humidity index (BGHI), according to equation 3:

$$
B G H I=T b g+0.36 T_{d p}+41.5
$$

where,

Tbg - black globe temperature, ${ }^{\circ} \mathrm{C}$; and

Tpo - dew point temperature, ${ }^{\circ} \mathrm{C}$.

It was used a completely randomized design with three treatments: $\mathrm{Z}-0.26 \mathrm{~mm}$ zinc tile; AC - 6mm asbestos cement tile; and ACW - 6mm asbestos cement tile white painted on the upper face.

Data were statistically analyzed using the SisVar $5.1{ }^{\circledR}$ program, applying the Scott Knott test, at $1 \%$ probability. As a fundamental assumption, the Hartley test was performed to check the homogeneity of variances, with the square root transformation applied when required, or angular transformation for data expressed in percentages.

\section{RESULTS AND DISCUSSION}

Table 1 presents mean values of daily dry bulb temperature $(\mathrm{Tdb})$, relative humidity $(\mathrm{RH})$ and enthalpy $(\mathrm{H})$ obtained from the external environment of the experiment without shading, and in the shelters with different types of roofs at different times of the day.

It is observed that there was a significant difference $(\mathrm{P}<0.01)$ in $\mathrm{Tdb}$, and in all treatments. The time with the lowest Tdb was $9 \mathrm{am}$, followed by $11 \mathrm{am}$ and $1 \mathrm{pm}$, with $1 \mathrm{pm}$ the time of highest $\mathrm{Tdb}$. It is also possible to observe significant differences in $\mathrm{Tdb}$ values between treatments at different times, being that at $9 \mathrm{am}$, the treatments showing lowest $\mathrm{Tdb}$ levels were ACW $\left(23.74{ }^{\circ} \mathrm{C}\right)$ and $\mathrm{AC}\left(23.84{ }^{\circ} \mathrm{C}\right)$, followed by $\mathrm{Z}\left(25.26^{\circ} \mathrm{C}\right)$, and at this time the external environment presented the highest value of $\mathrm{Tdb}\left(26.6^{\circ} \mathrm{C}\right)$. At $11 \mathrm{am}$ the treatments with the lowest $\mathrm{Tdb}$ were $\mathrm{AC}\left(26.18{ }^{\circ} \mathrm{C}\right)$ and $\mathrm{ACW}\left(26.52{ }^{\circ} \mathrm{C}\right)$, while $\mathrm{Z}\left(28.08{ }^{\circ} \mathrm{C}\right)$ did not differ from the value found in the external environment $\left(28.75^{\circ} \mathrm{C}\right)$, a fact that was repeated at $1 \mathrm{pm}$, with the lowest $\mathrm{Tdb}$ found in ACW 
treatments $\left(27.76^{\circ} \mathrm{C}\right)$ and $\mathrm{AC}\left(27.92^{\circ} \mathrm{C}\right)$, and again with no significant difference between $\mathrm{Z}$ $\left(29.50{ }^{\circ} \mathrm{C}\right)$ and the external environment $\left(30.07^{\circ} \mathrm{C}\right)$.

TABLE 1. Average dry bulb temperature $(\mathrm{Tdb})$, relative humidity $(\mathrm{RH})$ and enthalpy $(\mathrm{H})$ at different times of collection.

\begin{tabular}{cccc}
\hline Treatment / time & $9: 00 \mathrm{AM}$ & $11: 00 \mathrm{AM}$ & $13: 00 \mathrm{PM}$ \\
\hline \multicolumn{4}{c}{ Dry bulb temperature $(\mathrm{Tdb})$} \\
\hline Outside & $26.60 \mathrm{aC}$ & $28.75 \mathrm{bB}$ & $30.07 \mathrm{cB}$ \\
$\mathrm{Z}$ & $25.26 \mathrm{aB}$ & $28.08 \mathrm{bB}$ & $29.50 \mathrm{cB}$ \\
AC & $23.84 \mathrm{aA}$ & $26.18 \mathrm{bA}$ & $27.92 \mathrm{cA}$ \\
ACW & $23.74 \mathrm{aA}$ & $26.52 \mathrm{bA}$ & $27.76 \mathrm{cA}$ \\
\hline \multicolumn{5}{c}{ Relative humidity $(\mathrm{RH})$} \\
\hline Outside & $66.63 \mathrm{aA}$ & $57.07 \mathrm{bA}$ & $51.88 \mathrm{bA}$ \\
$\mathrm{Z}$ & $69.84 \mathrm{aA}$ & $57.55 \mathrm{bA}$ & $51.71 \mathrm{cA}$ \\
AC & $76.98 \mathrm{aB}$ & $65.70 \mathrm{bB}$ & $68.37 \mathrm{cB}$ \\
ACW & $77.56 \mathrm{aB}$ & $67.19 \mathrm{bB}$ & $70.38 \mathrm{~b}$ \\
\hline \multicolumn{4}{c}{} \\
\hline Outside & $66.28 \mathrm{a}$ & $66.94 \mathrm{a}$ & 67.96 \\
$\mathrm{Z}$ & 65.32 & 67.52 & $68.2 \mathrm{~b}$ \\
AC & $63.94 \mathrm{a}$ & $66.89 \mathrm{~b}$ & $68.40 \mathrm{~b}$ \\
\hline ACW & $64.47 \mathrm{a}$ & $68.24 \mathrm{~b}$ &
\end{tabular}

Means followed by same letter do not differ by the Scott Knott test at $1 \%$ probability, being considered for analysis, uppercase letters vertically, and lowercase letters horizontally. Z - zinc tile, CA - asbestos-cement tile; CAB - asbestos-cement tile painted white.

Regarding to $\mathrm{Tdb}$, it is possible to say that all values remained outside the zone of thermal comfort for newly born animals, which according to CURTIS (1983) is between $18{ }^{\circ} \mathrm{C}$ and $21{ }^{\circ} \mathrm{C}$. It was also observed that except for $9 \mathrm{am}$, Tdb remained above the upper critical temperature $\left(26^{\circ} \mathrm{C}\right)$ in all other observation times, being that above this temperature there is a tendency to occur decrease in production due to energy expenditure of the animal to thermoregulation.

In the analysis of RH values, it was observed that there was significant difference between treatments $(\mathrm{P}<0.01)$, and the performance in environments with different types of roof was similar, with the time with highest RH was 9am, followed by $11 \mathrm{am}$ and $1 \mathrm{pm}$, respectively. In the external environment, the behavior differed from individual shelters, and at 9am, the time of the highest RH, and $11 \mathrm{am}$ and $1 \mathrm{pm}, \mathrm{RH}$ values were lower but not statistically different. At 9am, the treatments showing the highest RH values were ACW (77.56\%) and AC (76.98\%), differing from Z (69.84\%) and from the external environment $(66.63 \%)$ with $\mathrm{RH}$ values significantly lower. Such behavior was repeated in the other treatments, with 11 am showing the highest RH values found for ACW (67.19\%) and $\mathrm{AC}(65.70 \%)$, differing from $\mathrm{Z}(57.55 \%)$ and the external environment $(57.07 \%)$. As for $1 \mathrm{pm}$, the highest average $\mathrm{RH}$ was for $\mathrm{ACW}(60.19 \%)$ and $\mathrm{AC}(58.37 \%)$, differing from $\mathrm{Z}$ $(51.71 \%)$ and the external environment $(51.88 \%)$.

In relation to enthalpy, it was observed that in all treatments, except for $\mathrm{Z}$, there was a significant difference among observation times; however, there was no significant difference between treatments at different times. It was observed that in the external environment, the lowest values of enthalpy were found at $9 \mathrm{am}(66.28 \mathrm{~kJ} / \mathrm{kg})$ and $11 \mathrm{am}(66.94 \mathrm{~kJ} / \mathrm{kg})$, with the highest value of enthalpy found at $1 \mathrm{pm}(70.38 \mathrm{~kJ} / \mathrm{kg})$. For the AC treatment, the lowest enthalpy was found at $9 \mathrm{am}(63.94 \mathrm{~kJ} / \mathrm{kg})$, being that at other times the enthalpydid not differ, being significantly higher than that at $9 \mathrm{am}$, with an average of $66.89 \mathrm{~kJ} / \mathrm{kg}$ and $68.2 \mathrm{~kJ} / \mathrm{kg}$ at $11 \mathrm{am}$ and $1 \mathrm{pm}$, respectively. The same behavior was observed for ACW, with the lowest enthalpy found at $9 \mathrm{am}(64.47 \mathrm{~kJ} / \mathrm{kg})$, and at other times the enthalpy were significantly higher than that at $9 \mathrm{am}$, with averages of $68.24 \mathrm{~kJ} / \mathrm{kg}$ and $68.40 \mathrm{~kJ} / \mathrm{kg}$ at $11 \mathrm{am}$ and $1 \mathrm{pm}$, respectively. 
According to KAWABATA et al. (2005) and PEREIRA (2007), the critical enthalpy for calves is $66.1 \mathrm{~kJ} / \mathrm{kg}$, with the fact that only at $9 \mathrm{am}$, the calculated enthalpy values stayed within the comfort zone for calves inside the shelters, and at all other times of observation, the enthalpy was above the critical enthalpy, presenting a situation of environmental stress to the animals. Also, in any of the collection times, enthalpy value was observed inthe external environment within the comfort zone for the calves in the studied region.

The data on daily averages of Tdb, RH Tbg, BGHI, MRT and TLR in the shelters with different types of roof are in Table 2.

TABLE 2. Average dry bulb temperature (Tdb), relative humidity $(\mathrm{RH})$, black globe temperature (Tbg), Globe Temperature and Humidity Index (BGHI), mean radiant temperature (MRT) and Thermal Load of Radiance (TLR).

\begin{tabular}{crrrrrr}
\hline Environmental & \multicolumn{3}{c}{ Treatments } & \multirow{2}{*}{ Average } & \multirow{2}{*}{ C.V. } & \multirow{2}{*}{ Prob. F } \\
\cline { 2 - 4 } Variables & $\mathrm{Z}$ & $\mathrm{AC}$ & ACW & & \\
\hline Tdb & $27.66 \mathrm{~b}$ & $25.95 \mathrm{a}$ & $26.09 \mathrm{a}$ & 26.57 & 9.38 & 0.0003 \\
RH & $59.37 \mathrm{~b}$ & $67.07 \mathrm{a}$ & $68.32 \mathrm{a}$ & 64.92 & 5.87 & 0.0019 \\
Tbg & $29.70 \mathrm{~b}$ & $27.74 \mathrm{a}$ & $27.16 \mathrm{a}$ & 28.20 & 9.83 & 0.0001 \\
BGHI & $81.63 \mathrm{~b}$ & $77.41 \mathrm{a}$ & $76.84 \mathrm{a}$ & 77.86 & 5.22 & 0.0118 \\
MRT & $304.26 \mathrm{a}$ & $306.77 \mathrm{~b}$ & $304.37 \mathrm{a}$ & 305.13 & 0.97 & 0.0001 \\
TLR & $523.44 \mathrm{c}$ & $506.72 \mathrm{~b}$ & $489.28 \mathrm{a}$ & 506.48 & 4.23 & 0.0002 \\
\hline
\end{tabular}

Means followed by same letter do not differ by the Scott Knott test at 1\% probability. Z - zinc tile, AC - asbestos cement tile; ACW asbestos cement tile white painted.

It is observed that there was a significant difference $(\mathrm{P}<0.01)$ for $\mathrm{Tdb}$, and daily averages were lowest in treatments $\mathrm{AC}\left(25.95^{\circ} \mathrm{C}\right)$ and $\mathrm{ACW}\left(26.09{ }^{\circ} \mathrm{C}\right)$, with no significant difference between the use of reflective paint and its absence in the asbestos-cement roof, with the highest average found in the $\mathrm{Z}$ treatment $\left(27.66^{\circ} \mathrm{C}\right)$.

There was also no significant difference for $\mathrm{RH}(\mathrm{P}<0.01)$, and the highest values found in ACW treatments $(68.32 \%)$ and AC (67.07\%), while the lowest value was found in $\mathrm{Z}(59.37 \%)$.

The same trend shown by Tdb was observed for values of Tbg and BGHI, with the lowest Tbg values found in $\mathrm{ACW}\left(27.16^{\circ} \mathrm{C}\right)$ and $\mathrm{AC}\left(27.74{ }^{\circ} \mathrm{C}\right)$, and the highest value in $\mathrm{Z}\left(29.70{ }^{\circ} \mathrm{C}\right)$. The lowest BGHI values were found in ACW (76.84) and AC (77.41), while the highest value was obtained in Z (81.63).

MRT had lower values in Z (304.26) and ACW (304.37), with the largest value found in AC (306.77).

TLR had shown no significant difference among all treatments $(\mathrm{P}<0.01)$, with the lowest value found in ACW treatment (489.28), while the highest value found in $\mathrm{Z}$ (523.44), being AC (506.72) with an intermediate value. Table 3.

The values of BGHI, MRT and TLR in the treatment during different times are shown in

It is observed that for BGHI, there was significant difference $(\mathrm{P}<0.01)$ only for treatment $\mathrm{Z}$ between the times of measurement, with the lowest value found at 9am (77.61), and the highest values found at $11 \mathrm{am}$ and $1 \mathrm{pm}$ with 82.35 and 84.94 , respectively. In all other treatments, there were not observed significant differences between BGHI during the times of measurement. 
TABLE 3. Average values obtained by time in different treatments for the environmental variables BGHI, MRT and TLR.

\begin{tabular}{|c|c|c|c|}
\hline Treatment / time & 9:00 am & 11:00 am & $13: 00 \mathrm{pm}$ \\
\hline \multicolumn{4}{|c|}{ Globe Temperature and Humidity Index (BGHI), } \\
\hline $\mathrm{Z}$ & $77,61 \mathrm{a}$ & $82,35 \mathrm{~b}$ & $84,94 \mathrm{~b}$ \\
\hline $\mathrm{AC}$ & 74,80 & 77,46 & 79,51 \\
\hline $\mathrm{ACW}$ & 74,89 & 76,87 & 78,81 \\
\hline \multicolumn{4}{|c|}{ Mean Radiant Temperature (MRT) } \\
\hline $\mathrm{Z}$ & $311,43 \mathrm{~B}$ & $307,71 \mathrm{~B}$ & 310,06 \\
\hline $\mathrm{AC}$ & $305,68 \mathrm{~A}$ & $306,77 \mathrm{~B}$ & 307,64 \\
\hline $\mathrm{ACW}$ & $305,28 \mathrm{~A}$ & $302,47 \mathrm{~A}$ & 305,63 \\
\hline \multicolumn{4}{|c|}{ Thermal Load of Radiance (TLR) } \\
\hline $\mathrm{Z}$ & $539,40 \mathrm{~B}$ & $498,22 \mathrm{~B}$ & 497,14 \\
\hline $\mathrm{AC}$ & $510,56 \mathrm{~A}$ & $503,22 \mathrm{~B}$ & 477,02 \\
\hline ACW & $526,00 \mathrm{~A}$ & $509,50 \mathrm{~A}$ & 495,69 \\
\hline
\end{tabular}

Means followed by same letter do not differ by the Scott Knott test at $1 \%$ probability, being considered for analysis, uppercase letters vertically, and lowercase letters horizontally. Z - zinc tile, AC - asbestos cement tile; ACW - asbestos cement tile white painted.

For MRT, there was no significant difference between the times of measurement in the different treatments $(\mathrm{P}>0.01)$, observing only significant difference between treatments 9am and $11 \mathrm{am}$. At 9am observation, the treatment with the largest value of TLR was Z (311.43), while lower values were found in ACW (305.28) and AC (305.68). At 11am, the lowest value of MRT was found in ACW (302.47), which was significantly higher than the values found in AC (306.77) and Z (307.71). At 1pm, the MRT values did not differ between treatments.

TLR did not show significant difference between treatments in the different collection times $(\mathrm{P}>0.01)$, and the only significant difference occurring between treatments 9am and 11am. At 9am, the treatment with highest TLR was Z (539.40), and significantly lower values were observed for AC (510.56) and ACW (526.00). At 11am, the lowest value of TLR was found in ACW (509.50), with significantly higher values observed for AC (503.22) and Z (498.22). At 11am, there was no significant difference between treatments.

\section{CONCLUSIONS}

The treatment $\mathrm{Z}$ showed the highest averages of $\mathrm{Tdb}$, Tbg, BGHI and TLR, characterizing a situation of greater thermal discomfort to the animal.

The white paint on the asbestos-cement tile promoted the best thermal performance of the material, providing an environment with better thermal comfort and less thermal load of radiation.

\section{REFERENCES}

BAÊTA, F.C.; SOUZA, C.F. Ambiência em edificações rurais: Conforto animal. 2.ed. Viçosa: Editora UFV, 2010. 269 p.

BUFFINGTON, D.E.; COLAZZO-AROCHO, A.; CANTON, G.H.; PITT, D. Black globe-humidity index (BGHI) as comfort equation for dairy cows. Transactions of the ASAE, St. Joseph, v.24, p.711-714, 1981.

CAMPOS, A.T.; KLOSOWSKI, E.S.; GASPARINO, E.; CAMPOS, A.T. de; SANTOS, W.B.R. Análise térmica de abrigos individuais móveis e sombrite para Bezerros. Acta Scientiarum Animal Sciences, Maringá, v.27, n.1, p.153-161, 2005. 
CONCEIÇÃO, M.N.; ALVES, S.P.; JÚNIOR, A.T.; SILVA, I.J.O.; PIEDADE, S.M.S.; JUNIOR, H.S.; TOLONI, G. Desempenho de telhas de escória de alto forno e fibras vegetais em protótipos de galpões. Revista Brasileira de Engenharia Agrícola e Ambiental, Campina Grande, v.12, n.5, p.536539, 2008.

CURTIS, S.E. Environmental managementin animal agriculture. Ames: The lowa State University Press, 1983. 409 p.

ESMAY, M.L. Principles of animal environment. Westport: AVI Publisher, 1979. 325 p.

FERREIRA, R. Comparação de vários materiais de cobertura através dos índices de conforto térmico. 1993. 49 f. (Graduação em Agronomia) - Faculdade de Agronomia de Ituverava Dr. Francisco Maeda, Fundação Educacional de Ituverava, Ituverava, 1993.

FERREIRA, R.A. Maior produção com melhor ambiente para aves, suínos e bovinos. Viçosa: Aprenda Fácil, 2005. 371 p.

FIORELLI, J.; MORCELI, J.A.B.; VAZ, R.I.; DIAS, A.A. Avaliação da eficiência térmica de telha reciclada à base de embalagens longa vida. Revista Brasileira de Engenharia Agrícola e Ambiental, Campina Grande, v.13, n.2, p.204-209, 2009.

KAWABATA, C. Y. ; CASTRO, R. C. ; SAVASTANO JUNIOR, H. . Índices de conforto térmico e respostas fisiológicas de bezerros da raça holandesa em bezerreiros individuais com diferentes coberturas. Engenharia Agrícola, Jaboticabal, v. 25, n. 3, p. 598-607, 2005.

MEDEIROS , C.M.; BAÊTA, F.C.; OLIVEIRA, R.F.M.; TINÔCO, I.F.F., ALBINO, L.F.T.; CECON, P.R. Índice térmico ambiental de produtividade para frangos de corte, Revista Brasileira de Engenharia Agrícola e Ambiental, Campina Grande, v.9, n.4, p.660-665, ago. 2005.

MELO, E.C.; LOPES, D.C.; CORRÊA, P.C. Grapsi - Programa computacional para o cálculo das propriedades psicrométricas do ar (2004). Disponível em:

<http://www.ufv.br/dea/reveng/arquivos/vol12/v12n2p154-162.pdf>. Acesso em: 24 jun. 2011.

MILANI, A.P.; SOUZA, F.A. de. Granjas leiteiras na região de Ribeirão Preto - SP. Engenharia Agrícola, Jaboticabal, 2010, v.30, n.4, p.742-752, 2010.

NAVARINI, F.C.; KLOSOWSKI, E.S.; CAMPOS, A.T.; TEIXEIRA. R.A.; ALMEIDA, C.P. Conforto térmico de bovinos da raça nelore a pasto sob diferentes condições de sombreamento e a pleno sol. Engenharia Agrícola, Jaboticabal, v.29, n.4, p.508-517, 2009.

PEREIRA, C. Monitoramento eletrônico do conforto térmico em abrigos individuais para bezerros com coberturas alternativas. Ensaios e Ciência, Piracicaba, v.5, n.5, p.73-76, 2007.

PERISSINOTTO, M.; MOURA, D.J.; MATARAZZO, S.V.; SILVA, I.J.O.; LIMA, K.A.O. Efeito da utilização de sistemas de climatização nos parâmetros fisiológicos do gado leiteiro. Engenharia Agrícola, Jaboticabal, v.26, n.3, p.663-671, set./dez. 2006.

SARMENTO, L.G.V.; DANTAS, R.T.; FURTADO, D.A.; NASCIMENTO, J.W.B.; SILVA, J.H.V. Efeito da pintura externa do telhado sobre o ambiente climático e desempenho de frangos de corte. Agropecuária Técnica, Areia, v.26, n.2, p.117-122, jan./mar.2005.

SILVA, I.J.O.; SEVEGNANI, K.B. Ambiência na produção de aves de postura. In: SILVA, I.J.O. Ambiência na produção de aves em clima tropical. SBEA: Jaboticabal, p.150-214, 2001.

TCPO 13. Tabela para composição de preços e orçamentos. São Paulo: PINI, 2008.

WEST, J.W. Effects of heat-stress on production in dairy cattle. Journal of Dairy Science, Champaign, v.86, n.6, p.2131-2144, 2003. 